University of Nebraska - Lincoln

DigitalCommons@University of Nebraska - Lincoln

Faculty Papers and Publications in Animal

Science

Animal Science Department

$10-24-2006$

Comparison of heat tolerance of feedlot heifers of different breeds

Tami M. Brown-Brandl

USDA-ARS U.S. Meat Animal Research Center, Tami.BrownBrandl@ARS.USDA.GOV

John A. Nienaber

USDA-ARS U.S. Meat Animal Research Center, john.nienaber@ars.usda.gov

Roger A. Eigenberg

USDA-ARS, USMARC, Clay Center, NE, roger.eigenberg@ars.usda.gov

Terry L. Mader

University of Nebraska-Lincoln, tmader1@unl.edu

J.L. Morrow

USDA-ARS SPA

See next page for additional authors

Follow this and additional works at: https://digitalcommons.unl.edu/animalscifacpub

Part of the Animal Sciences Commons

Brown-Brandl, Tami M.; Nienaber, John A.; Eigenberg, Roger A.; Mader, Terry L.; Morrow, J.L.; and Dailey, J.W., "Comparison of heat tolerance of feedlot heifers of different breeds" (2006). Faculty Papers and Publications in Animal Science. 1.

https://digitalcommons.unl.edu/animalscifacpub/1

This Article is brought to you for free and open access by the Animal Science Department at DigitalCommons@University of Nebraska - Lincoln. It has been accepted for inclusion in Faculty Papers and Publications in Animal Science by an authorized administrator of DigitalCommons@University of Nebraska - Lincoln. 


\section{Authors}

Tami M. Brown-Brandl, John A. Nienaber, Roger A. Eigenberg, Terry L. Mader, J.L. Morrow, and J.W. Dailey 


\title{
Comparison of heat tolerance of feedlot heifers of different breeds
}

\author{
T.M. Brown-Brandl ${ }^{\text {a,* }}$, J.A. Nienaber ${ }^{\text {a }}$, R.A. Eigenberg ${ }^{\text {a }}$, \\ T.L. Mader ${ }^{\text {b }}$, J.L. Morrow ${ }^{\text {c, }}$, J.W. Dailey ${ }^{\mathrm{d}}$ \\ ${ }^{\text {a }}$ USDA-ARS U.S. Meat Animal Research Center, P.O. Box 166, Clay Center, NE 68933, USA \\ ${ }^{\mathrm{b}}$ Extension and Research, University of Nebraska, Haskell Agricultural Lab, 57905866 Rd, Concord, NE 68728, USA \\ ${ }^{\mathrm{c}}$ USDA-ARS SPA, Lubbock, TX, USA \\ ${ }^{\mathrm{d}}$ USDA-ARS SPA, 125 Animal Science Bldg, Texas Tech University, Lubbock, TX 79409, USA
}

Received 16 February 2006; received in revised form 10 April 2006; accepted 18 April 2006

\begin{abstract}
Heat stress in cattle causes decreases in feed intake and feed efficiency; in extreme cases, it can cause death. These losses amount to millions of dollars each year. A study was designed to determine severity of heat stress among four breeds of cattle. Throughout two summers, 256 feedlot heifers of four different breeds were observed. Respiration rates, panting scores, and surface temperatures were taken twice each day on 10 animals/breed for several weeks during the summers of 2002 and 2003. Twenty-four-hour behavior measurements were recorded for four heat-stress and four thermoneutral days. Results showed during the afternoon, Angus cattle (black) had the highest respiration rates, panting scores, and surface temperatures, followed by the MARC III (dark red), Gelbvieh (tan), and Charolais (white). Behavior data showed that heat stress increased drinking and standing behavior, and decreased eating, lying, and agonistic behaviors, and that dark-hided cattle adjusted their behavior more than light-hided cattle. Overall, it was found that breed of cattle with dark-hides were more affected by temperature changes and at peak temperatures than breeds of cattle with light-hides.
\end{abstract}

(C) 2006 Elsevier B.V. All rights reserved.

Keywords: Feedlot cattle; Heat stress; Respiration rate; Panting score; Color

\section{Introduction}

Heat stress in cattle causes decreases in feed intake and growth, and in extreme cases can cause death.

\footnotetext{
* Corresponding author. Tel.: +1 402/762 4279; fax: +1 402/762 4273 .

E-mail address: brandl@email.marc.usda.gov (T.M. Brown-Brandl)

Deceased.
}

Heat stress occurs when the weather patterns change suddenly and the temperature increases rapidly, or temperatures remain high for several consecutive days with little or no recovery at night. A heat wave is "a period of abnormally uncomfortable hot and unusually humid weather of at least one day duration, but conventionally lasting several days to several weeks...." (AMS, 1989). Heat waves can cause production losses due to poor growth and feed efficiency, particularly in feedlot animals, and, in rare

1871-1413/\$ - see front matter (C) 2006 Elsevier B.V. All rights reserved. doi:10.1016/j.livsci.2006.04.012 
cases, can cause extensive death losses when the magnitude of the heat loads are coupled with little opportunity for nighttime recovery (Hahn et al., 1999).

A heat wave in July, 1995, caused the loss of approximately 3750 head of cattle in western Iowa; direct losses were estimated at $\$ 2.8$ million and production losses at \$28million (Busby and Loy, 1996). A producer survey conducted after the heat wave indicated death loss was greater in dark-hided cattle and in pens that faced west/southwest instead of east/southeast. The death loss was substantially less in pens that provided shade for the animals $(0.4 \%$ vs. $4.8 \%)$.

In July, 1999, a heat wave killed over 5000 head of cattle in northeast Nebraska. A subsequent analysis of the death loss was performed to identify risk factors attributed to loss of the individual animals (Hungerford et al., 2000; Mader et al., 2001). They found that heavier cattle were at higher risk than lighter weight cattle, and black cattle had a 5.7 times higher risk of mortality than the other coat colors.

The objectives for this study were to determine the effects of breed on the heat tolerance of cattle by evaluating changes in behavior, respiration rate, panting scores, hair surface temperatures, and feed intake.

\section{Materials and methods}

Two-hundred and fifty-six feedlot heifers of four breeds (Angus, Charolais, Gelbvieh, and MARC III crossbred [Pinzgauer, Red Poll, Hereford, Angus]) from the USDA-ARS U.S. Meat Animal Research Center's (USMARC) population were selected for this study ( 32 heifers/breed/year). The study was conducted over two consecutive summers (2002-2003) in the USMARC feedlot located $9.6 \mathrm{~km}$ west and $3.2 \mathrm{~km}$ north of Clay Center, Nebraska. Angus cattle were all black, MARC III were mostly dark red (a total of three animals over a 2-year period were black), Gelbvieh were tan in color, and Charolais were all white or off-white. The breeds of cattle used in this experiment had hide colors that corresponded to the reported hair color (Angus - Black hair and black hide, MARC III - dark red hair and dark red hide, Gelbvieh - tan hair and tan hide, Charolais - white hair and pink hide). Heifers initially weighing
$393.5 \pm 45.4 \mathrm{~kg}$ (mean \pm standard deviation) were assigned to one of four adjacent pens by breed ( 32 heifers/pen). To simulate standard feedlot practices, heifers were implanted with Synovex-H $(200 \mathrm{mg}$ testosterone propionate and $20 \mathrm{mg}$ esteordial benzoate) to promote growth, 40 days before the study began. Heifers were fed twice daily, before $0800 \mathrm{~h}$ and after $1300 \mathrm{~h}$, and had free access to water at all times. Live weights and body condition scores were recorded every 28 days. Condition scores were taken on an expanded 27-point scale (Table 1) due to the close similarity of cattle using the traditional 9-point scale.

Throughout the study, weather data (dry-bulb temperature, dew-point temperature, solar radiation, wind speed, and wind direction) were collected using an automated weather station (Vantage Pro, Davis Industries) located in the middle of the set of four pens (Fig. 1). This data served as the source of current weather data. The weather data collected by the South Central Station of the Automated Weather Data Network [AWDN], operated by the High Plains Regional Climate Center Central Weather Station located $1 \mathrm{~km}$ east of the feedlot pens, was

Table 1

Comparison of standard and expanded 27-point visual body condition score scale

\begin{tabular}{|c|c|c|}
\hline $\begin{array}{l}\text { 9-point } \\
\text { scale }\end{array}$ & $\begin{array}{l}\text { 27-point } \\
\text { scale }\end{array}$ & Description $^{\mathrm{a}}$ \\
\hline 1 & $1-3$ & $\begin{array}{l}\text { Extremely thin, all skeletal structures } \\
\text { are visible }\end{array}$ \\
\hline 2 & $4-6$ & Very thin. Skeletal structures are visible \\
\hline 3 & $7-9$ & $\begin{array}{l}\text { Thin. Muscle tissue is evident, but } \\
\text { not abundant }\end{array}$ \\
\hline 4 & $10-12$ & $\begin{array}{l}\text { Marginal, ribcage backbone junction } \\
\text { becoming less visible }\end{array}$ \\
\hline 5 & $13-15$ & $\begin{array}{l}\text { Muscle tissue is nearing maximum, } \\
\text { fat deposit behind shoulder is noticeable, } \\
\text { ribs are covered slightly }\end{array}$ \\
\hline 6 & $16-18$ & $\begin{array}{l}\text { Muscle tissue volume is at a maximum, } \\
\text { fat deposit behind shoulder is obvious, } \\
\text { ribs are covered completely with fat } \\
\text { beginning to cover rump }\end{array}$ \\
\hline 7 & $19-21$ & $\begin{array}{l}\text { Fat deposits behind shoulder and at } \\
\text { tailhead are obvious, flat appearance } \\
\text { is beginning to dominate topline }\end{array}$ \\
\hline 8 & $22-24$ & $\begin{array}{l}\text { Fat deposits are flattening rump, } \\
\text { fat is filling brisket and over shoulder }\end{array}$ \\
\hline 9 & $25-27$ & $\begin{array}{l}\text { Obese, flat appearance dominates, } \\
\text { brisket is heavy }\end{array}$ \\
\hline
\end{tabular}

\footnotetext{
${ }^{a}$ Descriptions from Hardin (1990).
} 


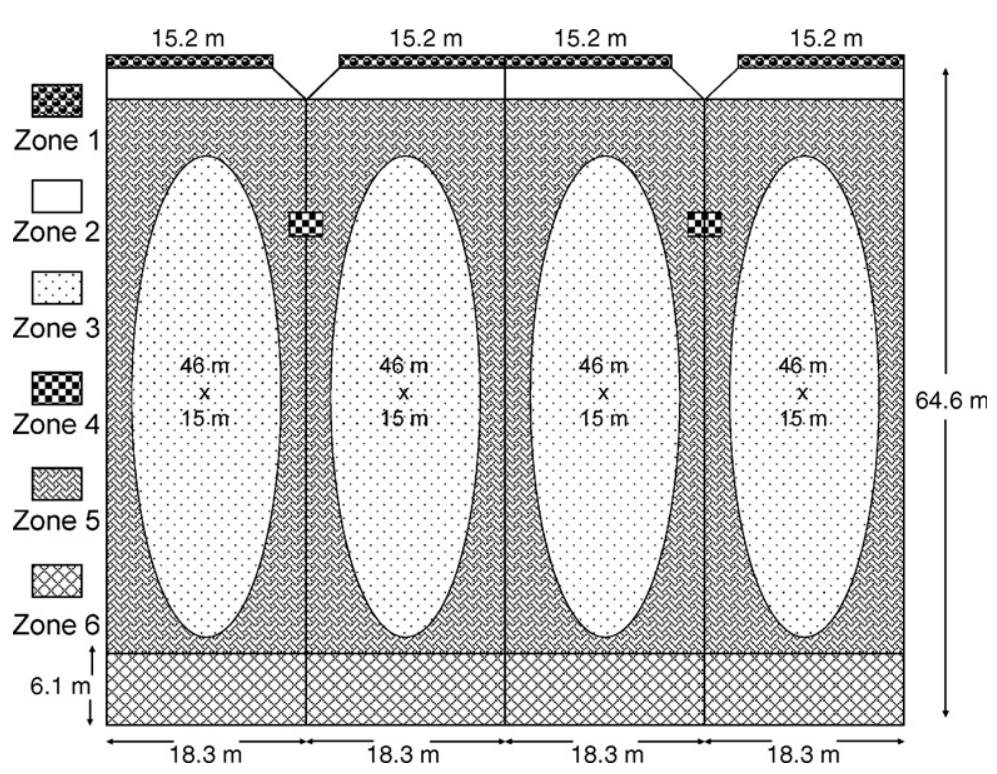

Fig. 1. Graphical representation of the six zones used to assess animal behavior.

used as a source of daily high, low, and average temperatures, dew-points, wind speeds, and solar radiation measurements.

Ten days prior to initiating the following two experiments, cattle were preconditioned to the observers. During the preconditioning period, two observers spent $1 \mathrm{~h}$ twice daily walking outside the pens.

\subsection{Physiological stress indicators}

This experiment focused on the individual measurements of physiological stress indicators (respiration rate, panting score, and surface temperatures). Measurements of respiration rate, panting score (Table 2 ), and surface temperature were made twice daily $(0800$ and $1430 \mathrm{~h})$ on a predetermined schedule. In 2002, measurements were taken during six periods of 5 days each from June until August. In 2003, measurements were taken during twelve periods of 3 to 5 days in length from May until August. On scheduled experimental days, two observers, working independently, randomly selected five animals per pen to observe. One of the observers started in Pen 1 and worked toward Pen 4, while the other observer started in Pen 4 and worked toward Pen 1. For each selected animal, animal identification number, standing or lying behavior, panting score (Mader and Davis,
2002), and respiration rate were recorded. Respiration rates were determined by visual observation of flank movement, timing 10 breaths with a stopwatch. After the respiration rate and panting score measurements were completed, surface temperature measurements were taken with an infrared thermometer (Raynger ST80 ProPlus; $\pm 1^{\circ} \mathrm{C}$ ). Measurements were recorded on five heifers per pen on the animals' back, at approximately the last rib from a distance of less than $3 \mathrm{~m}$. No identification numbers were recorded in conjunction with the surface temperature measurements. Prior to the initiation of the measurements, and immediately following the conclusion of the measurements, the current weather data (temperature, dew-

Table 2

Description of panting scores

\begin{tabular}{ll}
\hline Score & Description $^{\text {a }}$ \\
\hline 0 & $\begin{array}{l}\text { Normal respiration, } \sim 60 \text { or less breaths } / \mathrm{min} \\
1\end{array}$ \\
2 & $\begin{array}{l}\text { Slightly elevated respiration, } 60-90 \mathrm{breaths} / \mathrm{min} \\
\text { or small amount of saliva, } 90-120 \text { breaths } / \mathrm{min}\end{array}$ \\
3 & $\begin{array}{l}\text { Heavy open-mouthed panting; saliva usually } \\
\text { present, } 120-150 \text { breaths } / \mathrm{min}\end{array}$ \\
4 & $\begin{array}{l}\text { Severe open-mouthed panting accompanied by } \\
\text { protruding tongue and excessive salivation }\end{array}$ \\
\hline
\end{tabular}

\footnotetext{
${ }^{a}$ Panting scores were assigned based on visual observation of
} behavior, not on the estimation of respiration rates. 
point, wind speed, and solar radiation) were recorded. The average of these two weather measurements served as weather data for analysis purposes.

The general linear model procedure in SAS (SAS, 2000) was used to analyze the respiration rate, panting score, and surface temperature data. Analyses were conducted using daily values, in addition to separate analyses of the morning and afternoon measurements. The statistical model is as follows:

$y_{i j}=\mu+\alpha_{i}+\beta_{j}+\alpha \beta_{i j}+\gamma_{k}\left(x_{i j k}-\overline{x_{. .}}\right)+\varepsilon_{i j}$

where: $\mu$ is the overall mean, $\alpha_{i}$ is the effect of the $i$ th breed, $\beta_{j}$ is the effect of the $j$ th year, $\alpha \beta_{i j}$ is the interaction term of $i$ th breed in the $j$ th year, $\gamma_{k}$ is the slope for the linear effect of parameter $x_{i j k}$, and the error term of $\varepsilon_{\mathrm{ij}}$. For surface temperature, the following five weather parameters are included: $x_{i j 1}$ is the deviation of temperature from its mean; $x_{i j 2}$ is the squared deviation of temperature from its mean; $x_{i j 3}$ is the deviation of dew-point from its mean; $x_{i j 4}$ is the deviation of wind speed from its mean; $x_{i j 5}$ is the deviation of solar radiation from its mean. For respiration rate and panting score, two additional parameters are included: $x_{i j 6}$ is the deviation of condition score from its mean; $x_{i j 7}$ is the deviation of weight from its mean. Hence $\mathrm{n}$ is 5 or 7 depending on the analyzed trait.

\subsection{Behavior traits}

The heifer behavior was assessed during 4 selected days per year for a total of 8 days: 4 thermoneutral days and 4 heat stress days. Thermoneutral days (TN) were defined as days when the maximum dry-bulb temperature did not exceed $28^{\circ} \mathrm{C}$. Heat-stress days (HS) were defined as a day when the maximum dry-bulb temperature exceeded $35^{\circ} \mathrm{C}$ and there was little cloud cover (less than 10\%). In order to assess animal behavior and position, the pens were categorized into six zones: Zone 1-feed bunk, Zone 2-waiting to eat, Zone 3-the mound, Zone 4-waterer, Zone 5beside the mound, Zone 6 - the back $1 / 4$ of the pen (Fig. 1). The following behaviors were classified: eating, drinking, standing, lying, agonistic, and mounting. During the observation days, behaviors were observed by a scan sampling technique (Mitloehner et al., 2001) every $15 \mathrm{~min}$ during the daytime hours (0530-1900h), and every $1 \mathrm{~h}$ during nighttime hours (2000-0500h), using a handheld spotlight with a red lens cover. Each observation included both a behavior and a location for every animal in each pen. Behavior observations commenced at midnight and concluded at midnight the following day.

The behavioral data was reduced to hourly readings throughout the day by averaging the number of animals in each category. The percentages were transformed using the square root-arc-sine or angular transformation to ensure normally distributed data (Kuehl, 1994). The transformed data were then analyzed with the general linear model procedure in SAS using the following model statement.

$y_{i j}=\mu+\alpha_{i}+\beta_{j}+\delta_{k}+\gamma_{l}+\alpha \beta_{i j}+\varepsilon_{i j}$

where: $\mu$ is the overall mean, $\alpha_{i}$ is the effect of the $i$ th breed, $\beta_{j}$ is the effect of the $j$ th year, $\delta_{k}$ is effect of time of day, and $\gamma_{l}$ is the effect of temperature (TN or HS).

\section{Results and discussion}

Beginning and ending weights and condition scores, along with ages and average gains over the experimental period, are listed in Table 3. There were significant differences in beginning weights, condition scores, and ages in the four populations of animals used. All animals used were born during the spring calving season of the previous year. To account for these differences, weight and condition scores were used as covariates in subsequent analyses on individual animal measurements (respiration rate and panting scores).

\subsection{Physiological stress indicators}

Average daily respiration rates were significantly affected by animal weight and condition score, the linear and quadratic effect of dry-bulb temperature, dew-point, solar radiation, wind speed, breed, and year (Table 4). The darker colored breeds, Angus (96.6 breaths/min) and the MARC III (95.6breaths/ min), had significantly $(P<0.05)$ higher respiration rates than either the Gelbvieh ( 88.7 breaths $/ \mathrm{min}$ ) or the Charolais ( 80.7 breaths/min). Average daily panting score is a visual indication of stress level and is related to respiration rate (Mader and Davis, 2002). The effects on panting score were similar to respiration 
Table 3

Average ages, weights, condition scores, and gains

\begin{tabular}{|c|c|c|c|c|c|c|c|c|}
\hline & \multicolumn{4}{|l|}{$2002^{*}$} & \multicolumn{4}{|l|}{2003} \\
\hline & Angus & MARC III & Gelbvieh & Charolais & Angus & MARC III & Gelbvieh & Charolais \\
\hline Beginning ag & $430.9 \pm 2.7^{\mathrm{a}}$ & $449.8 \pm 2.7^{\mathrm{b}}$ & $443.6 \pm 2.7^{\mathrm{bc}}$ & $441.0 \pm 2.7^{\mathrm{c}}$ & $395.5 \pm 2.8^{\mathrm{a}}$ & $404.5 \pm 2.7^{b}$ & $423.6 \pm 2.7^{\mathrm{c}}$ & $419.8 \pm 2^{c}$ \\
\hline Beginning weight $(\mathrm{kg})$ & $372.7 \pm 6.8^{\mathrm{a}}$ & $353.5 \pm 6.8^{\mathrm{b}}$ & $406.9 \pm 6.8^{\mathrm{c}}$ & $406.5 \pm 6.8^{c}$ & $393.6 \pm 6.9^{\mathrm{a}}$ & $366.6 \pm 6.8^{\mathrm{b}}$ & $421.7 \pm 6.8^{\mathrm{c}}$ & $426.1 \pm 6.8^{\mathrm{c}}$ \\
\hline Beginning condition score & $19.2 \pm 0.3^{\mathrm{a}}$ & $16.9 \pm 0.3^{\mathrm{b}}$ & $14.1 \pm 0.3^{\mathrm{c}}$ & $15.2 \pm 0.3^{\mathrm{d}}$ & $19.5 \pm 0.3^{\mathrm{a}}$ & $18.8 \pm 0.3^{\mathrm{a}}$ & $18.0 \pm 0.3^{\mathrm{b}}$ & $17.0 \pm 0.3^{\mathrm{c}}$ \\
\hline Ending weight $(\mathrm{kg})$ & $462.1 \pm 7.7^{\mathrm{a}}$ & $451.1 \pm 7.7^{\mathrm{a}}$ & $508.6 \pm 7.7^{\mathrm{b}}$ & $513.8 \pm 7.7^{\mathrm{b}}$ & $510.0 \pm 7.9^{\mathrm{a}}$ & $471.2 \pm 7.7^{\mathrm{b}}$ & $527.0 \pm 7.7^{\mathrm{c}}$ & $542.1 \pm 7.7^{\mathrm{c}}$ \\
\hline Ending condition score & $23.9 \pm 0.2^{\mathrm{a}}$ & $23.3 \pm 0.2^{\mathrm{a}}$ & $21.7 \pm 0.2^{\mathrm{b}}$ & $22.0 \pm 0.2^{\mathrm{c}}$ & $26.0 \pm 0.2^{\mathrm{a}}$ & $24.7 \pm 0.2^{\mathrm{b}}$ & $23.3 \pm 0.2^{\mathrm{c}}$ & $22.9 \pm 0.2^{\mathrm{c}}$ \\
\hline Gain (kg/day) & $1.5 \pm 0.05^{\mathrm{a}}$ & $1.6 \pm 0.05^{\mathrm{b}}$ & $1.7 \pm 0.05^{\mathrm{bc}}$ & $1.8 \pm 0.05^{\mathrm{c}}$ & $1.5 \pm 0.05^{\mathrm{a}}$ & $1.3 \pm 0.05^{\mathrm{b}}$ & $1.3 \pm 0.05^{\mathrm{b}}$ & $1.5 \pm 0.05^{\mathrm{a}}$ \\
\hline
\end{tabular}

* Columns with differing superscripts are significantly different $(P<0.05)$.

rate; animal condition score, the linear and quadratic effect of dry-bulb temperature, dew-point, solar radiation, wind speed, breed, and year $(P<0.05)$ affected panting score. Panting scores were significantly different for all breeds (Angus [0.58], MARC III [0.52], Gelbvieh [0.37], and Charolais [0.29]). The high respiration rate and panting score of the darkhided cattle relate to a higher stress level (BrownBrandl et al., 2005; Eigenberg et al., 2000; Eigenberg et al., 2005; Mader and Davis, 2002). This higher stress level in the dark-hided cattle can be mostly explained by the higher daily surface temperature of the darkhided cattle (Angus $\left[38.7^{\circ} \mathrm{C}\right]$ and MARC III $\left[37.4^{\circ} \mathrm{C}\right]$ ) compared to the Gelbvieh $\left(35.7^{\circ} \mathrm{C}\right)$ and the Charolais $\left(33.1^{\circ} \mathrm{C}\right)$. Busby and Loy (1996) reported results of a producer's survey taken to identify contributing factors to a 1995 heat wave in western Iowa. They found that producers with non-shaded lots had the highest death loss in dark-hided animals. These results indicate that dark-hided cattle have a higher stress load, which might indicate that they are predisposed to death in an extreme temperature situation. Furthermore, Hungerford et al. (2000) and Mader et al. (2001), in their analyses of the 1999 heat wave in northeastern Nebraska, found black cattle to be at a 5.7 times greater risk of death than other cattle. In the current study, average daily respiration rate did not indicate any significant differences between black- (Angus) and red- (MARC III crossbred) hided cattle, but panting score and surface temperature did indicate differences.

Even under the low stress conditions of the morning readings, differences are apparent. Surface temperatures showed the most separation between the breeds and were affected by dry-bulb temperature, solar radiation, wind speed, breed, year and the breed $\times$ year interaction (Angus $\left[34.6^{\circ} \mathrm{C}\right]$, MARC III $\left[33.7^{\circ} \mathrm{C}\right]$,

Table 4

Treatment means

\begin{tabular}{|c|c|c|c|c|c|}
\hline & Angus* & MARC III & Gelbvieh & Charolais & Statistics** \\
\hline \multicolumn{6}{|l|}{ Morning } \\
\hline Respiration rate (breaths/min) & $74.8 \pm 1.0^{\mathrm{a}}$ & $75.9 \pm 1.0^{\mathrm{a}}$ & $74.0 \pm 0.9^{\mathrm{a}}$ & $67.6 \pm 0.9^{\mathrm{b}}$ & $\mathrm{Wt}, \mathrm{CS}, t_{\mathrm{db}}^{2}, \mathrm{Rad}, \mathrm{WS}, \mathrm{B}, \mathrm{Y}, \mathrm{B} \times \mathrm{Y}$ \\
\hline Panting score & $0.16 \pm 0.02^{\mathrm{a}}$ & $0.14 \pm 0.02^{\mathrm{a}}$ & $0.11 \pm 0.02^{\mathrm{a}}$ & $0.06 \pm 0.02^{\mathrm{b}}$ & $\mathrm{Wt}, t_{\mathrm{db}}, t_{\mathrm{db}}^{2}, \mathrm{Rad}, \mathrm{WS}, \mathrm{B}, \mathrm{B} \times \mathrm{Y}$ \\
\hline Surface temperature $\left({ }^{\circ} \mathrm{C}\right)$ & $34.6 \pm 0.3^{\mathrm{a}}$ & $33.7 \pm 1.6^{\mathrm{b}}$ & $32.2 \pm 1.6^{\mathrm{c}}$ & $30.0 \pm 1.6^{\mathrm{d}}$ & $t_{\mathrm{db}}, \mathrm{Rad}, \mathrm{WS}, \mathrm{B}, \mathrm{Y}, \mathrm{B} \times \mathrm{Y}$ \\
\hline \multicolumn{6}{|l|}{ Afternoon } \\
\hline Respiration rate (breaths/min) & $116.2 \pm 1.4^{\mathrm{a}}$ & $113.5 \pm 1.4^{\mathrm{a}}$ & $103.3 \pm 1.3^{\mathrm{b}}$ & $94.1 \pm 1.3^{\mathrm{c}}$ & $\mathrm{CS}, t_{\mathrm{db}}^{2}, \mathrm{Rad}, \mathrm{WS}, t_{\mathrm{dp}}, \mathrm{B}, \mathrm{Y}$ \\
\hline Panting score & $0.96 \pm 0.03^{\mathrm{a}}$ & $0.86 \pm 0.03^{b}$ & $0.61 \pm 0.03^{\mathrm{c}}$ & $0.50 \pm 0.03^{\mathrm{d}}$ & $\mathrm{CS}, t_{\mathrm{db}}, t_{\mathrm{db}}^{2}, \mathrm{Rad}, \mathrm{WS}, t_{\mathrm{dp}}, \mathrm{B}, \mathrm{Y}$ \\
\hline Surface temperature $\left({ }^{\circ} \mathrm{C}\right)$ & $42.6 \pm 0.1^{\mathrm{a}}$ & $40.9 \pm 0.1^{\mathrm{b}}$ & $39.0 \pm 0.1^{\mathrm{c}}$ & $36.0 \pm 0.1^{\mathrm{d}}$ & $t_{\mathrm{db}}, \mathrm{Rad}, \mathrm{WS}, t_{\mathrm{dp}}, \mathrm{B}, \mathrm{Y}, \mathrm{B} \times \mathrm{Y}$ \\
\hline \multicolumn{6}{|l|}{ Daily } \\
\hline Respiration rate (breaths/min) & $96.6 \pm 0.9^{\mathrm{a}}$ & $95.6 \pm 0.9^{\mathrm{a}}$ & $88.7 \pm 0.8^{\mathrm{b}}$ & $80.7 \pm 0.8^{\mathrm{c}}$ & $\mathrm{Wt}, \mathrm{CS}, t_{\mathrm{db}}, t_{\mathrm{db}}^{2}, \mathrm{Rad}, \mathrm{WS}, t_{\mathrm{dp}}, \mathrm{B}, \mathrm{Y}$ \\
\hline Panting score & $0.58 \pm 0.02^{\mathrm{a}}$ & $0.52 \pm 0.02^{\mathrm{b}}$ & $0.37 \pm 0.02^{\mathrm{c}}$ & $0.29 \pm 0.02^{\mathrm{d}}$ & $\mathrm{CS}, t_{\mathrm{db}}, t_{\mathrm{db}}^{2}, \mathrm{Rad}, \mathrm{WS}, t_{\mathrm{dp}}, \mathrm{B}, \mathrm{Y}$ \\
\hline Surface temperature $\left({ }^{\circ} \mathrm{C}\right)$ & $38.7 \pm 0.2^{\mathrm{a}}$ & $37.4 \pm 0.2^{\mathrm{b}}$ & $35.7 \pm 0.2^{\mathrm{c}}$ & $33.1 \pm 0.2^{\mathrm{d}}$ & $t_{\mathrm{db}}, \mathrm{Rad}, \mathrm{WS}, t_{\mathrm{dp}}, \mathrm{B}, \mathrm{B} \times \mathrm{Y}$ \\
\hline
\end{tabular}

* Columns with differing superscripts are significantly different $(P \leq 0.05)$.

** Abbreviations indicate significant effects $(P \leq 0.05)$. Definitions of abbreviations: $\mathrm{B}=$ breed; $\mathrm{CS}=\mathrm{condition}$ score; $\mathrm{Wt}=\mathrm{weight}$; $\mathrm{Y}=\mathrm{year}$ of experiment $(2002,2003) ; t_{\mathrm{db}}=$ ambient dry-bulb temperature $\left({ }^{\circ} \mathrm{C}\right) ; t_{\mathrm{dp}}=$ ambient dew-point temperature $\left({ }^{\circ} \mathrm{C}\right) ; \operatorname{Rad}=\operatorname{solar} \mathrm{radiation}\left(\mathrm{W} / \mathrm{m}^{2}\right)$; $\mathrm{WS}=$ wind speed $(\mathrm{m} / \mathrm{s})$. Weather parameters were measured at the time of the animal readings. 
Gelbvieh $\left[32.2^{\circ} \mathrm{C}\right]$, and Charolais $\left.\left[30.0^{\circ} \mathrm{C}\right]\right)$. Respiration rate was affected by weight, condition score, drybulb temperature squared, solar radiation, wind speed, breed, year and breed $\times$ year, while panting score was not affected by condition score of the animal, but had the additional significant effect of dry-bulb temperature. Both panting score and respiration rate showed that the Charolais had less stress in the morning than the other breeds (panting score - Charolais [0.06], Angus [0.16], MARC III [0.14], and Gelbvieh [0.11]; respiration rate - Charolais [67.6 breaths $/ \mathrm{min}$ ], Angus [74.8breaths/min], MARC III [75.9breaths/min], and Gelbvieh [74.0 breaths/min]).

The afternoon panting score and surface temperature were significantly different in all breeds. Panting score was affected by condition score, dry-bulb temperature, dry-bulb temperature squared, solar radiation, wind speed, dew-point, breed, and year; respiration rate had the additional significant effect of animal weight. Angus and MARC III heifers had higher respiration rates than either Gelbvieh or Charolais heifers. Gelbvieh heifers had significantly higher respiration rates than Charolais heifers. However, Angus only tended to be higher than the MARC III $(P=0.088)$. The Angus cattle tend to have the highest respiration rate (116.2 breaths/min), highest panting scores (0.96), and highest surface temperature $\left(42.6^{\circ} \mathrm{C}\right)$, followed by the MARC III respiration rate (113.5 breaths/min), panting score (0.86), surface temperature $\left(40.9^{\circ} \mathrm{C}\right)$, then the Gelbvieh respiration rate ( 103.3 breaths $/ \mathrm{min})$, panting score $(0.61)$, surface temperature $\left(39.0^{\circ} \mathrm{C}\right)$, and lastly the Charolais respiration rate $(94.1$ breaths $/ \mathrm{min})$, panting score $(0.50)$, and surface temperature $\left(36.0^{\circ} \mathrm{C}\right)$. The difference between black Angus and the dark red MARC III was very small: a $2.7 \%$ difference in respiration rate and a $4 \%$ difference in surface temperature. Panting score indicated the largest difference between black and red, with a $12 \%$ difference. There was a large difference in responses between the dark red MARC III and the tan Gelbvieh $(9.2 \%$ for respiration rate, $31.8 \%$ for panting score, and $4.7 \%$ for surface temperature). The differences between the Gelbvieh and the Charolais were similar to those found between the Gelbvieh and the MARC III (9.1\% for respiration rate, $21.7 \%$ for panting score, and $7.7 \%$ for surface temperature).

\subsection{Behavior traits}

The results of the behavior study are summarized in Table 5. The behavior data were originally analyzed by breed; however, due to a lack of significance dark-

Table 5

Least square means (\% of observations)

\begin{tabular}{|c|c|c|c|c|c|c|c|}
\hline & \multicolumn{3}{|c|}{ Heat stress* (HS) } & \multicolumn{3}{|c|}{ Thermoneutral (TN) } & \multirow[t]{2}{*}{ Statistics** } \\
\hline & $\begin{array}{l}\text { Dark-hided } \\
\text { (Angus, } \\
\text { MARC III) }\end{array}$ & $\begin{array}{l}\text { Light-hided } \\
\text { (Gelbvieh, } \\
\text { Charolais) }\end{array}$ & Average & $\begin{array}{l}\text { Dark-hided } \\
\text { (Angus, } \\
\text { MARC III) }\end{array}$ & $\begin{array}{l}\text { Light-hided } \\
\text { (Gelbvieh, } \\
\text { Charolais) }\end{array}$ & Average & \\
\hline Eat & $6.8 \pm 0.5^{\mathrm{a}}$ & $7.3 \pm 0.5^{\mathrm{ab}}$ & $7.1 \pm 0.3$ & $10.0 \pm 0.4^{\mathrm{c}}$ & $8.2 \pm 0.5^{\mathrm{b}}$ & $9.1 \pm 0.3$ & $\mathrm{~T}, \mathrm{H}, \mathrm{Y}, \mathrm{C} \times \mathrm{T}, \mathrm{T} \times \mathrm{H}, \mathrm{T} \times \mathrm{Y}, \mathrm{H} \times \mathrm{Y}, \mathrm{T} \times \mathrm{H} \times \mathrm{Y}$ \\
\hline Drink & $3.7 \pm 0.1^{\mathrm{a}}$ & $2.6 \pm 0.1^{\mathrm{b}}$ & $3.1 \pm 0.1$ & $1.9 \pm 0.1^{\mathrm{c}}$ & $1.5 \pm 0.1^{\mathrm{d}}$ & $1.7 \pm 0.1$ & $\begin{array}{l}\mathrm{T}, \mathrm{C}, \mathrm{H}, \mathrm{Y}, \mathrm{T} \times \mathrm{H}, \mathrm{T} \times \mathrm{Y}, \mathrm{H} \times \mathrm{Y} \\
\mathrm{C} \times \mathrm{T} \times \mathrm{Y}, \mathrm{T} \times \mathrm{H} \times \mathrm{Y}\end{array}$ \\
\hline Stand & $48.3 \pm 1.0^{\mathrm{a}}$ & $47.9 \pm 1.0^{\mathrm{a}}$ & $48.1 \pm 0.7$ & $40.3 \pm 1.0^{\mathrm{b}}$ & $43.6 \pm 1.1^{\mathrm{c}}$ & $42.0 \pm 0.7$ & $\mathrm{~T}, \mathrm{C}, \mathrm{H}, \mathrm{Y}, \mathrm{C} \times \mathrm{T}, \mathrm{T} \times \mathrm{H}, \mathrm{H} \times \mathrm{Y}, \mathrm{T} \times \mathrm{H} \times \mathrm{Y}$ \\
\hline Lying & $40.7 \pm 1.1^{\mathrm{a}}$ & $41.5 \pm 1.1^{\mathrm{a}}$ & $41.1 \pm 0.8$ & $44.4 \pm 1.1^{\mathrm{b}}$ & $44.2 \pm 1.2^{\mathrm{b}}$ & $44.3 \pm 0.8$ & $\mathrm{~T}, \mathrm{H}, \mathrm{T} \times \mathrm{H}, \mathrm{H} \times \mathrm{Y}, \mathrm{C} \times \mathrm{T} \times \mathrm{Y}, \mathrm{T} \times \mathrm{H} \times \mathrm{Y}$ \\
\hline Agonistic & $0.2 \pm 0.5^{\mathrm{a}}$ & $0.3 \pm 0.5^{\mathrm{a}}$ & $0.2 \pm 0.4$ & $3.3 \pm 0.4^{\mathrm{b}}$ & $2.0 \pm 0.5^{\mathrm{b}}$ & $2.6 \pm 0.4$ & $\mathrm{~T}, \mathrm{H}, \mathrm{T} \times \mathrm{H}, \mathrm{H} \times \mathrm{Y}, \mathrm{T} \times \mathrm{H} \times \mathrm{Y}$ \\
\hline Mount & $0.3 \pm 0.06^{\mathrm{a}}$ & $0.4 \pm 0.06^{\mathrm{a}}$ & $0.4 \pm 0.05$ & $0.1 \pm 0.06^{\mathrm{b}}$ & $0.4 \pm 0.07^{\mathrm{a}}$ & $0.3 \pm 0.05$ & $\mathrm{C}, \mathrm{H}, \mathrm{C} \times \mathrm{T}, \mathrm{C} \times \mathrm{H}^{\dagger}, \mathrm{H} \times \mathrm{Y}$ \\
\hline Area $2 * * *$ & $1.5 \pm 0.2^{\mathrm{a}}$ & $1.6 \pm 0.2^{\mathrm{ac}}$ & $1.6 \pm 0.1$ & $2.2 \pm 0.2^{\mathrm{b}}$ & $1.7 \pm 0.2^{\mathrm{bc}}$ & $2.0 \pm 0.1$ & $\mathrm{~T}, \mathrm{H}, \mathrm{T} \times \mathrm{H}, \mathrm{H} \times \mathrm{Y}, \mathrm{T} \times \mathrm{H} \times \mathrm{Y}$ \\
\hline Area 3 & $3.3 \pm 1.1^{\mathrm{a}}$ & $4.4 \pm 1.1^{\mathrm{a}}$ & $3.8 \pm 0.8$ & $22.8 \pm 1.1^{\mathrm{b}}$ & $32.0 \pm 1.2^{\mathrm{c}}$ & $27.4 \pm 0.8$ & $\begin{array}{l}\mathrm{T}, \mathrm{C}, \mathrm{H}, \mathrm{Y}, \mathrm{C} \times \mathrm{T}, \mathrm{T} \times \mathrm{H}, \mathrm{T} \times \mathrm{Y}, \mathrm{C} \times \mathrm{Y}, \mathrm{H} \times \mathrm{Y} \\
\mathrm{C} \times \mathrm{T} \times \mathrm{Y}, \mathrm{T} \times \mathrm{H} \times \mathrm{Y}\end{array}$ \\
\hline Area 5 & $54.2 \pm 1.6^{\mathrm{ab}}$ & $56.2 \pm 1.6^{\mathrm{b}}$ & $55.2 \pm 1.1$ & $51.5 \pm 1.5^{\mathrm{a}}$ & $47.9 \pm 1.7^{\mathrm{b}}$ & $49.7 \pm 1.1$ & $\mathrm{~T}, \mathrm{H}, \mathrm{Y}, \mathrm{T} \times \mathrm{H}, \mathrm{C} \times \mathrm{Y}, \mathrm{H} \times \mathrm{Y}, \mathrm{T} \times \mathrm{H} \times \mathrm{Y}$ \\
\hline Area 6 & $30.5 \pm 1.2^{\mathrm{a}}$ & $27.8 \pm 1.2^{\mathrm{a}}$ & $29.1 \pm 0.9$ & $11.6 \pm 1.2^{\mathrm{b}}$ & $8.7 \pm 1.3^{\mathrm{b}}$ & $10.1 \pm 0.9$ & $\mathrm{~T}, \mathrm{C}^{\dagger}, \mathrm{H}, \mathrm{Y}, \mathrm{T} \times \mathrm{H}, \mathrm{T} \times \mathrm{Y}, \mathrm{H} \times \mathrm{Y}, \mathrm{T} \times \mathrm{H} \times \mathrm{Y}$ \\
\hline
\end{tabular}

* Columns with different superscripts are significantly different $(P<0.05)$.

** Abbreviations indicate significant effects at the $P \leq 0.05$ or the $P<0.1$ level if marked by ${ }^{\dagger}$. Definitions of abbreviations: $\mathrm{T}=$ temperature (heat stress, thermoneutral); $\mathrm{C}=$ light or dark hide color; $\mathrm{H}=$ hour of the day; $\mathrm{Y}=$ year of experiment.

*** Area 2=waiting to eat; Area 3=mound; Area 5=area surrounding the mound; Area $6=$ back $1 / 4$ of the pen; Areas 1 and 4 were not analyzed separately because animals could only eat or drink, respectively, in those areas. 
hided (Angus and MARC III) and light-hided (Gelbvieh and Charolais) were grouped together. Behavior data is stated in percentage of animals expressing a particular behavior or in a particular area on average throughout the day.

During heat stress, eating behavior decreased (7.1\% vs. $9.1 \%)$, drinking behavior increased $(3.1 \%$ vs. $1.7 \%)$, standing behavior increased $(48.1 \%$ vs. $42.0 \%)$, lying behavior decreased ( $41.1 \%$ vs. $44.3 \%)$, and agonistic behavior decreased ( $2.6 \%$ vs. $0.2 \%)$ for HS and TN, respectively. These results seem to match reports from commercial feedlots. Mounting behavior did not change with temperature; animals under HS conditions spent $0.4 \%$ of the time mounting, compared to $0.3 \%$ for the animals under $\mathrm{TN}$ conditions. Animals spent more time in the area surrounding the mound (Area 5: 55.2\% vs. 49.7\%), and less time on the mound (3.8\% vs. $27.4 \%)$ during HS than TN, respectively. Although not analyzed, during heat stress the animals tended to stand in large groups around the waterer.

When behavior was analyzed, color by temperature treatment differences arose. The dark-hided heifers spent significantly $(P<0.05)$ less time eating, lying, and being agonistic, and significantly $(P<0.05)$ more time drinking, standing, and mounting under heat stress conditions than in thermoneutral conditions. Dark-hided heifers also spent less time waiting to eat (Area 2) and on the mound (Area 3), and more time at the back of the pen (Area 6) in the hot weather. The light-hided heifers spent less time lying and being agonistic, and more time drinking and standing. Lighthided heifers also spent less time on the mound (Area 3), and more time at the back of the pen (Area 6). To summarize these results, it appears that the dark-hided heifers changed their behavior more than the lighthided heifers, possibly because they were more stressed.

\section{Conclusion}

It was found that breeds of cattle with dark-hides (Angus and MARC III) had higher respiration rates, panting scores, and surface temperatures than the breeds of cattle with light-colored hides (Charolais and Gelbvieh). Behavioral observations revealed that heat-stressed cattle decreased eating, lying, and agonistic behavior, and increased drinking and standing behavior. It was found that the dark-hided heifers adjusted their behavior more extensively than the light-hided cattle, indicating that these animals were more stressed. This shift in behavior, along with the higher respiration rate, panting score, and surface temperature are indications that breeds of cattle with dark hides (Angus and MARC III) are more stressed under summer conditions than light-hided cattle (Gelbvieh and Charolais). Our results, supported by literature data, suggest that under extreme weather conditions black-hided (Angus) cattle will have a higher stress level than other colors.

\section{Acknowledgements}

The authors would like to thank Tanner Augustin, Todd Boman, Andrea Finzel, John Holman, Dan Marintzer, Diane Purcell, Krystal Zimmerman for their help in collecting data, and Elda Patton for help in preparation of the manuscript.

\section{References}

A.M.S., 1989. Glossary of Meteorology, 5th ed. American Meteorological Society, Boston, MA.

Brown-Brandl, T.M., Eigenberg, R.A., Hahn, G.L., Nienaber, J.A., Mader, T.L., Spiers, D.E., Parkhurst, A.M., 2005. Analyses of thermoregulatory responses of feeder cattle exposed to simulated heat waves. Int. J. Biometeorol. 49, 285-296.

Busby, D., Loy, D., 1996. Heat stress in feedlot cattle: producer survey results. Beef Research Report, A.S Leaflet R1348. Iowa State University, Ames, IA.

Eigenberg, R.A., Hahn, G.L., Nienaber, J.A., Brown-Brandl, T.M., Spiers, D., 2000. Development of a new respiration rate monitor for cattle. Trans. ASAE 43, 723-728.

Eigenberg, R.A., Brown-Brandl, T.M., Nienaber, J.A., Hahn, G.L., 2005. Dynamic response indicators of heat stress in shaded and non-shaded feedlot cattle: Part 2. Predictive relationships. Biosyst. Eng. 91, 111-118.

Hahn, G.L., Mader, T.L., Gaughan, J.B., Hu, Q., Nienaber, J.A., 1999. Heat waves and their impacts on feedlot cattle. Proc., 15th Int. Congress on Biometeorology \& Int. Conference on Urban Climatology, [ICB 13.1], Sydney, Australia.

Hardin, R., 1990. Using body condition scoring in beef cattle management. Circular 817. University of Georgia College of Agricultural and Environmental Sciences and the U.S. Department of Agriculture.

Hungerford, L.L., Buhman, M.J., Dewell, R.D., Mader, T.L., Griffin, D., Smith, D.R., Nienaber, J.A., 2000. Investigation of 
heat stress mortality in four midwest feedlots. Int. Symp. on Veterinary Epidemiology and Economics, No. 616. Breckenridge, $\mathrm{CO}$.

Kuehl, R.O., 1994. Statistical Principles of Research Design and Analysis. Duxbury Press, Belmont, CA.

Mader, T.L., Davis, M.S., 2002. Wind speed and solar radiation corrections for the temperature-humidity index. Proc., 15th Conference on Biometeorology and Aerobiology Joint with 16th Int. Congress on Biometeorology. Boston, MA.
Mader, T.L., Hungerford, L.L., Nienaber, J.A., Buhman, M.J., Davis, M.S., Hahn, G.L., Cerkoney, W.M., Holt, S.M., 2001. Heat stress mortality in Midwest feedlots. J. Anim. Sci. 79 (Supplement 2), 2.

Mitloehner, F.M., Morrow-Tesch, J., Wilson, S.C., Dailey, J.W., McGlone, J.J., 2001. Behavioral sampling techniques for feedlot cattle. J. Anim. Sci. 79, 1189-1193.

SAS User's Guide, 2000. Version 8. SAS Institute Inc., Cary, NC. 